\title{
Personality Theory in Gestalt Theoretical Psycho- therapy: Kurt Lewin's Field Theory and his Theory of Systems in Tension Revisited
}

\section{Introduction}

Psychotherapy is an intentional, planned, interactional process, which implies that the therapist has theoretical ideas about the human person and its functioning and about the nature and functioning of such an interactional process. Whether explicit or implicit, naïve or scientific, every psychotherapist has some kind of personality theory that guides her/his actions. One can understand a client's anxiety as a punishment from God, as an innate constitutional trait, a learned reaction, an expression of unresolved instinctual conflicts, or as a result of the client's psychological situation. Depending on her/his assumptions-whether or not she/he is aware of them-the therapist will experience the situation differently and will differently interact with her/him. Since psychotherapy schools consider themselves to be scientific, they are asked to make explicit assumptions, and thus also render these debatable and verifiable. By also reflecting on their own implicit, naïve, and prescientific personality conceptions, therapists further improve their ability to recognize and understand the naïve "personality theories" that underlie their clients' experiences.

Scientific personality theories intend to describe, explain, and predict the individual peculiarities in the experiencing and behavior of people. Usually, they include terms and concepts about the personality structure and its dynamics and development. To date, no consensual paradigm exists, but there are many different approaches in academic psychology and in the field of psychotherapy. According to an earlier "classic" in this field, Hall and Lindzey (1978), originally there were two main lines of personality theories, one emanating from the clinical area, from Gestalt psychology and the works of William Stern, and the other from empirical, natural science-oriented psychology. Since then, these lines have

\footnotetext{
Based on the lecture at the 21st International Convention of the Society of Gestalt Theory and its Applications "Motion - Spaces of Human Experience", 13th-15th June 2019, Warsaw, Poland.

2 I am very grateful to Gerhard Stemberger for initiating this contribution and for supporting and advising its creation with great knowledge and prudence.
}

○ Open Access. @ 2021 Bernadette Lindorfer, published by Sciendo. (c) BY-NC-ND This work is licensed under the Creative Commons Attribution NonCommercial-NoDerivatives 4.0 License. 
further differentiated: some were added, and others lost importance. However, a fundamental dividing line between the more holistic-oriented approaches from the clinical area and the behavioral, trait-oriented, factor-analytical, and biological (genetic and neurobiological) approaches of academic psychology remained noticeable (e.g., Weiner, Millon, \& Lerner, 2003; Corr \& Matthews, 2009).

Kurt Lewin's holistic, gestalt, and field-oriented personality theory had a high influence on the emerging personality psychology. It moved away from the prevailing static models of personality in favor of a dynamic one. Behavior is no longer seen as a manifestation of character or of traits, but as a functional part of the situation (Foschi \& Lombardo, 2006). Contrary to his initially great influence, interest in Lewin's concept of personality decreased at the end of the 20th century in the field of academic personality psychology. Thus, his personality theory can be found in the two-volume overview work by Hall \& Lindzey until the 1978-edition, but was no longer included in later editions. In contrast, other humanistic approaches and neo-psychoanalytic approaches are given more importance. Likewise, other recent publications on personality theories in academic psychology no longer deal explicitly with Kurt Lewin's field approach, although often the repercussions of his ideas and concepts are unmistakable even where his name is not mentioned. Various approaches which were developed in the framework of Lewin's field theory are still being pursued today without explicitly placing them in the context of a personality theory. For example, Lewin's theory of systems in tension occupies a prominent place in Heinz Heckhausen's standard work Motivation and Action (Heckhausen, 1991, 113-127) and continues to do so in the revised third edition (2018), which was published after Heckhausen's death, and in which his concept is contrasted with other models (Heckhausen \& Beckmann, 2018). ${ }^{3}$ Lewin's theory of systems in tension also underlies the still unbroken series of experimental research on the resumption of interrupted actions as well as the development of newer theories based on it, such as the concept of symbolic self-completion by Wicklund and Gollwitzer $(1981,1982)$ and the approaches that emerged from it.

There seems to be a difference here between the requirements for a personality theory in academic psychology and the requirements for one in psychotherapy. In academic psychology, the necessity and possibility of a personality theory can be assessed sometimes higher, sometimes lower in the course of the development of psychology. In psychotherapy, on the other hand, the entire therapeutic methodology depends on one's own personality-theory views and the concepts are put to the test day after day. It is therefore not surprising that Lewin's field theory

\footnotetext{
3 However, a possible contradiction between a "person model" (to which the systems in tensions are assigned) and an "environment model" (in which the valences in the environment play a central role) is suspected in Lewin's field theory by the authors, an assessment we do not follow.
} 
and his suggestions for understanding the person still play an important role in the field of psychotherapeutic theories and concepts. This is the case, for example, with group therapy methods, with group psychoanalysis (Foulkes, Bion) and system-centered therapy for groups by Yvonne M. Agazarian (1986, 2004), with the conditional genetic psychopathology of the catathymic-imaginative approach of HC Leuner (1997; Andersch, 2012), with Gestalt therapy (Wollants, 2008; Staemmler, 2005; Spagnuolo-Lobb, 2010), and also with the more recent fieldtheoretical approaches in psychoanalysis (Baranger \& Baranger, 2008).

This article aims to show how Kurt Lewin's concept of personality is understood and embedded in the theoretical framework of Gestalt theoretical psychotherapy and how it is put to practice there.

\section{Gestalt Theory as Field Theory}

For Gestalt theory and Gestalt theoretical psychotherapy, the epistemological viewpoint of critical realism, and thus the strict distinction between the phenomenal and the trans-phenomenal world and the specific understanding of the nature and function of the relations between these worlds, is crucial (Köhler, 1929; Bischof, 1966; Metzger, 1969; Stemberger, 2011; Sternek, 2021). The interrelation between the trans-phenomenal and the phenomenal world(s) is assumed to be isomorphic (Köhler, 1968; Luchins \& Luchins, 1999).

Gestalt theory is a field theory per se (Metzger, 1975/1986, 220). According to Tholey (1998) and Stemberger (2019), we can distinguish from among the phenomenal field, the psychic field, and the psychophysical field. These differentiations have also important implications for psychotherapy. The phenomenal field includes the phenomenal body-ego and its phenomenal environment. It is the everyday world of human experience, which we address mainly when we are "practicing phenomenology" with our clients. It is the world "in which we perceive, think, remember, plan, act, communicate, and interact" (ibid., 62). Extended by those (psychological) forces, which are phenomenally not given but show themselves through their action or effects-for example, Prägnanz tendency, frame of reference, and so on as quasi-phenomenal constructs in the field of Gestalt theory, or the id or the unconscious forces of defense or resistance as constructs in the field of depth psychology—it becomes a psychic/psychological field. The latter psychophysical field is a postulated central nervous field, which is simultaneously psychic and physical. In this respect, this concept contains the Gestalt-theoretical idea that mental processes are that part of the totality of central nervous processes which also has phenomenal properties and constitutes consciousness. It differs significantly from both parallelistic theories and approaches that attribute a causal relationship —in terms of cause and effect-between central nervous and psychological processes, the psyche, and the brain. 
Lewin's field approach, which is fundamental for the personality theory in Gestalt theoretical psychotherapy, deals with the psychological field. In Gestalt theoretical psychotherapy, Lewin's approach is consistently interpreted in a critical-realistic way, which, in some areas, leads to different results than those available in the writings of Lewin himself. As is well known, Kurt Lewin differed from the other founders of Gestalt theory in one essential point, namely, with regard to the necessity of a psychophysical theory, as proposed by Wertheimer, Köhler, and Koffka. This led to problems in Lewin's central concept of life space, whose relationship to the non-psychological environment of the life space remained contradictory in Lewin's work (Graefe presented a detailed study of this problem in 1961). However, these contradictions can be resolved on a criticalrealistic basis, which is now consistently carried out in the conceptualization of Gestalt theoretical psychotherapy. Without a solution to this problem, it would not be possible to adequately understand and treat the processes of people's encounters and relationships in psychotherapy, because here (like in everyday situations where people interact) not one but several life spaces come into play, and it is therefore necessary to understand how the mutual influences between these life spaces come about. ${ }^{4}$ Contrary to Lewin's view, this makes a psychophysical theory inevitable.

In other words, in Gestalt theoretical psychotherapy, the understanding of the experience and behavior of client and psychotherapist, as well as all other subconcepts of our psychotherapy conception, are consequently based on the field-theoretical approach of Gestalt theory. Yet, we are convinced that such a field theory has to be a psychophysical one (a view that with the "discovery" of the "4E" has meanwhile also gained attention in the cognitive sciences). In this respect, our concepts are built on the fruitful notions and findings of Lewin's field theory, but they do not follow its limitations on a purely psychological field theory. Instead, Gestalt Theoretical Psychotherapy integrates Lewin's concepts and findings into the general psychophysical field theory of the Gestalt theoretical approach, for which Köhler's isomorphism assumption is still the most plausible hypothesis governing the relationship between psychological and physical processes.

\section{Lewin's Field Theory}

\subsection{The concept of life space}

It was Lewin's scientific claim not to be satisfied with general laws about generalized people, but to develop a terminology that allows to explain the single case

\footnotetext{
Paul Tholey has pointed out that this problem has been underestimated in the initial publications on Gestalt Theoretical Psychotherapy (Tholey, 1996, 11f)
} 
and to answer the question of why in a particular case a given individual behaves in a given way and not otherwise (Lewin 1936, 11). Therefore, Lewin argues, we have to know the laws which control psychological events-for example, the dynamic laws in the field of needs and emotions - and the specific nature of the particular situation the person is placed in. Hence, the focus of investigation in Lewin's theory is the person-in-a-situation, which is called "life space." The life space with the person and her/his psychological environment is seen as a dynamic field that is continuously changing and encompasses everything that determines the person's experience and behavior at a given time.

The environment and the person are further articulated into "regions." The person is seen as a stratified system with central and peripheral regions. The regions of the environment are the quasi-social, quasi-physical, and quasi-conceptual facts, which we find therein. Regions are qualitatively different from each other and are separated by boundaries, which are more or less permeable. For our experience and behavior, it is of great importance in which way and to what degree these regions are connected or separated (Lewin, 1936, 42).

Not all regions of the life space are equally accessible to the person. We often find bodily, physical, social, or mental boundaries, which prevent us from locomotion to a special region. Yet, the solidity of the boundaries can be different with respect to the specific (bodily, social, or mental) sphere. Besides all kinds of physical, social, or mental barriers, the space of free movement is limited by insufficient (physical or mental) ability (Lewin, 1936, 45).

Our environment includes many objects and events having specific characteristics for us; some invite us to eat or drink them, some can protect us against cold or rain, another lures us to play with it, this relaxed person seems able to calm us down, that lively person to cheer us up ... The objects and events have a special "valence," as Lewin says, which is a "stimulating character," that invites us to act. Depending on our current goals and needs and the associated tension systems (see chapter 4), this valence can be positive or negative and varies in its strength (Lewin, 1935; Lück, 1996). So, when I am hungry, the bakery will catch my eye, while I do not notice the hairdresser's next to it. Having next day's job interview in mind, the hairdresser gets my attention and calls me in. Now the bakery doesn't mean anything to me and I may not even notice it. Needs and goals and the resulting valences do not always emanate from the person. They can also arise from the environment and can be induced especially by other persons and groups but also by environmental facts or events and their power fields.

Because it is a field, the facts in the life space (objects, persons, activities) are related to each other and the person and the environment must be regarded as being mutually interdependent. If and how an object, person, or event is experienced 
in our phenomenal world is therefore a result of a dynamic process of organization, in which at first the Gestalt properties of the object or event and the total configuration in the perceptual field play a substantial role. Beyond this, this field is not isolated, but is in close communication with the overall "inner" situation, especially the prevailing goals, intentions, and needs (cf. Soff, 2018). Therefore, there is a direct relationship between the momentary state of the individual and the structure of her/his psychological environment.

In this view, behavior is the result of change in some state of the field in a given unit of time. Behavior in Lewin's field-concept depends neither on the past nor on the future, but on the present field in the "here and now." Indubitably, of course, the present field has a certain time depth that includes both the psychological past and the psychological future with its expectations, wishes, and dreams (Lewin, 1936; 1942). ${ }^{5}$

The life space develops and changes during our entire life. As the individual matures and develops, the life space expands and its differentiation increases. Some regions become accessible, others close, and the valences of regions are, perhaps, changing.

\subsection{The concept of forces}

However, the state of intentions, needs, and goals of the person, on the one hand, and valences of objects and activities, on the other hand, do not determine sufficiently which behavior will occur. Thus, Lewin uses the concept of force. $\mathrm{He}$ postulates that all experience and behavior depend on the field forces which are operational between the person and his/her psychological environment. Forces are defined by their direction, their strength, and their point of application; and they are represented by vectors. To put it briefly, driving-field forces that correspond with positive valences cause us to move toward a goal or object, and field forces corresponding with negative valences cause us to move away from it. This is not only meant in a physical sense but also in a figurative sense. Barriers in the life space that prevent us from attaining a goal correspond with restraining forces. The totality of the forces present in the psychological field will control the direction of the process and thus the behavior (Lewin, 1946/1963).

In this process, we often meet conflicting forces. Therefore, we often have to pass a region with a negative valence to reach our goal, as when we first have to go through exams before we get the permission to work in a specific profession,

\footnotetext{
5 Lewin's 1942 publication "Time perspective and morale" is considered the foundation of psychological theory and research on time perspective. For some recent work on the psychological time depth, refer Nuttin, J. \& W. Lens (1985); Stolarski, M., N. Fieulaine \& W. van Beek (eds., 2015) and Zimbardo, P.C. \& J.N. Boyd (1999).
} 
or when we have to do boring and monotonous exercises before we get good at something. Sometimes, we are torn between two approximately equally attractive alternatives. However, since the balance is rather unstable, we are unlikely to remain trapped in this conflict for long. An approach in direction of one of the alternatives soon will lead to its predominance over the other. In other situations, we find, simultaneously, attraction and repulsion in the same place; consequently, at a certain point, there would be hesitation, a halt, or a back-and-forth movement in the approach to the goal.

Where the attainment of a goal is impeded by some barrier, the action toward the goal will not completely stop. It will initially push the action out of the original direction. However, if the individual runs against the barrier several times without success, the barrier itself acquires a negative valence. In addition to a positive vector, a negative one comes into existence.

When conflicts become very strong, it sometimes can happen that the individual no longer faces the conflict but "goes out of the field"; this can be physical again, but may also occur as resignation, inner emigration, etc. In every process, the forces in the inner and outer environment are changed by the process itself (Lewin, 1935, 48).

\section{Lewin's Theory of Systems in Tension}

Up to this we focused mainly on the interaction between the person and the environment and the associated forces in the life space. Now we turn more closely to the area of the person, especially to the sphere of the needs, intentions, and goals of the person, which is essential to the dynamics of the mind.

We know that every process that takes place presupposes energy that is set free and capable of doing the work: but where do these energies come from?

Kurt Lewin worked on this issue already in Berlin in the 1920s. In his publications, "Vorbemerkungen über die psychischen Kräfte und Energien und über die Struktur der Seele" [Preliminary Remarks on the Psychological Forces and Energies and on the Structure of the Mind] (1926a) and "Vorsatz, Wille und Bedürfnis [Intention, Will and Need]," (1926b), he formulated his fundamental ideas. At the same time, together with his co-workers and students, he began to carry out a series of investigations to test these theses experimentally. The results were published between 1926 and 1937 in about 20 articles, mainly in the journal "Psychologische Forschung" [Psychological Research].

In short, Lewin assumes that the energies required for behavior are to be found in psychic tensions that arise when there is a need, a wish, a purpose, or an intention. The latter are called "quasi needs." These psychic tensions are striving for discharge and thus make us ready for action: "The inner state of tension comes to 
a breakthrough as soon as the possibility of eliminating or at least alleviating the tension seems to exist, i.e., as soon as there is a situation in which one senses the possibility of actions in the direction of the goal" (Lewin, 1926b, 349; translation $\mathrm{BL}$ ). Once the need has been satisfied or the goal has been achieved, the tension lessens and the system finds a new equilibrium. This is the same, whether the tension stems from a genuine need, a quasi-need or a need which is induced by the power field of another person, group, or institution - they are functionally identical. Equally, the fulfillment of either need leads to the release of the tension and a reestablishment of an equilibrium (Lewin, 1926b; Brown, 1929; Marrow, 1969, 33).

Here we find some significant differences between Lewin's motivation theory and instinct or drive theories like Freud's: Lewin's concept is open to all sorts of motivational needs: basic bodily needs such as hunger, thirst, and sexuality as well as essential mental and social needs, for example, social bonding, self-esteem, belonging, curiosity, thirst for knowledge, self-efficacy, self-esteem, and others. Quasineeds, i.e., intentions, purposes, goals, and wishes, often derive from them and are in a close dynamic communication with them. Both needs and quasi-needs develop and change throughout life, and social factors and relationships play an important role in this. Thus, they can arise from altruistic motivation (an action is performed for the sake of another person), can be induced by the power field of another person or group ("induced needs"), or emerge from the state of belonging to a group and the desire to share and follow its goals (Lewin, 1946/1963). This has manifold implications for psychotherapy. Thus, it will be important to clarify with the client whether her/his behavior arises from her/his own needs and intentions or is induced by the power field of other persons or groups, which can be experienced either as supportive or restrictive (cf. Lindorfer, 2017). Related to this, the question of how the client can develop and strengthen her/his power field is of particular importance. Further, the success of the therapist-client jointeffort in psychotherapy will also depend on the extent to which the therapist can develop and flexibly use her/his power field toward the clients for their well-being (cf. Stemberger, 2017a,b).

In contrast to Lewin's conceptualization, drive theories mostly view the motivations underlying behavior as innate or inherent arising in development. They usually are understood as continuously acting in a certain direction. However, Lewin underlines that the efficacy of the drives is bound to the existence of acute states of tension (Lewin, 1928).

Mostly—and maybe also derived from Freud's view, that we strive for pleasure and avoid displeasure- the term "tension" is used to describe an unpleasant state of strain or stress; but this is not what Lewin meant with the term. According to 
his concept, "tension" is rather a desirable state because it is valuable for increasing a person's efforts to achieve a goal (cf. Marrow, 1969, 31f).

\section{Experimental Work of the Lewin Group on Tension Systems}

\subsection{Forgetting and remembering}

The basic experimental verification of Lewin's concept was carried out by Bluma Zeigarnik (1927) and Maria [Rickers-]Ovsiankina (1928/1976). Both are dealing with the tensions arising from taking on a task. Zeigarnik presented the subjects a number of tasks (22) to perform. The tasks were of all kinds and levels of difficulty, and included the likes of continuation of a honeycomb pattern, dissolve puzzle-rings, guesswork, laying mosaics of colored stones, solving jigsaw puzzles, threading pearls on a string, memory tests etc. Half of the tasks they were allowed to finish, while they were interrupted in the other half by the presentation of a new task at a time when they were well on the way to a solution. The subjects of course didn't know whether or why they would be allowed to complete a task or not. At the end of the session, the experimenter asked the subjects to tell her what they had been doing during the hour. Compared to the completed tasks, the unfinished tasks were recalled twice as often on average.

After Bluma Zeigarnik proved wrong some other possible explanations for these results (emotional shock by the interruption; did subjects expect to be asked later to complete the tasks?), she concluded that we must find the cause of the better recollection of the uncompleted tasks in the tension set up by the intended act which corresponds to a quasi-need:

The question of the experimenter "What have you been doing in this hour?" sets up a tension in the subject that will be relieved by the recall. Similarly, each task in the experiment had also set up a tension that was discharged when the task was completed, but remained unrelieved for the interrupted tasks. Therefore, at the moment of recall, two vectors exist, deriving from these two tensions: one driving in direction of the recall of all the tasks of the experiment, the other directed toward the completion of the unfinished tasks. The latter becomes effective also for the recall, making the unfinished tasks more readily available.

Bluma Zeigarnik's experiment was a first proof of the validity of Lewin's concept of psychic tension. It became very popular, and many follow-up studies were carried out. Its results were confirmed in most cases but couldn't always be replicated. This led to a refined understanding of the phenomenon. Hence, there is no evidence for an autonomous need to complete something we have started. The extent of retention is dependent on how committed we were to the task and whether the mastery of the task affected central personal goals, as, for example, 
our self-esteem. When the subjects' ambition is aroused, the number of uncompleted tasks at the recall grows enormously.

Furthermore, the expectations of the subjects have a significant impact on what will become figure and what will become ground. If my level of aspiration and my self-esteem are low, I will probably better recall the completed tasks, whereas someone whose self-esteem and level of aspiration are high is better in the recall of the unfinished tasks (Junker, 1960).

Another important finding of Zeigarnik was that tensions are not set up unless there is a certain stability in the total psychic field. In cases of fatigue and excitability, no tensions are established. As a result of subsequent emotional upsets, existing tension systems can be destroyed.

After a certain time - that is, in the course of a few days-tensions that stem from the unresolved tasks may disappear from natural causes (cf. Lindorfer 2012a).

\subsection{Resumption and completion}

If a purpose or an intention corresponds dynamically to a tension system, it is to be expected that once set up, it does not just affect memory but would also cause activities which serve the purpose of execution. This assumption was examined by Maria [Rickers-]Ovsiankina (1928/1976), another student of Lewin. Similar to Zeigarnik's experiments, the subjects were given different tasks and were interrupted in some of their activities. After a while, they were left alone in the room.

Ovsiankina discovered a natural tendency toward resumption. The vast majority of the subjects returned to the uncompleted activities to finish them off. When the experimenter forbade resumption, resumption of an underhand nature occurred. However, once an activity was completed and the goal was achieved, resumption failed to occur. Instead, there was relaxation, satisfaction, and an indifference to the task. The decisive factor here was the inner and not the outer goal of the action. In accordance with Zeigarnik's findings, the tendency for resumption in [Rickers-] Ovsiankina's study depended essentially on the subjects' attitudes toward the action. The more the subject gets involved in the act, the more likely it is to resume. Highest resumption rates occur when the person devotes herself/ himself to the task with "dedication." Again, ambition increases the frequency of resumption. In both cases, strong needs are addressed (cf. Lindorfer 2012b).

\subsection{Substitution: completion by replacement}

What happens if an action is interrupted and there is no way to resume and complete it? What happens to the tension then? What happens when the original inner goal of action can no longer be achieved? How can a conclusion be found in 
this case? These are the questions that Lewin's co-workers, Lissner (1933), Mahler (1933), and Sliosberg (1934) investigated in their experiments.

Käthe Lissner (1933) also used the technique of interrupted tasks to examine which sort of substitute actions could release the built up tension systems and so prevent the interrupted actions from being resumed. The extent to which the tendency to resume was reduced was defined as "substitute value." The factors "similarity" and "difficulty" turned out to be essential. Specifically, the similarity to the inner goal of the action is decisive and not the external similarity of the action. In addition, under identical circumstances, the more difficult action had a higher substitute value.

Wera Mahler's study (1933) revealed that substitute actions with a higher degree of reality are of more value than those with a lower degree. Hence, a substitute action is more likely to discharge the tension than a substitution by talking. Again, it is crucial to understand whether the person's inner goal is achieved. Thus, communicating a solution for a problem-task can already be a kind of realization, because it is creating a social fact, but doing so in implementation tasks-such as building a tower-is not sufficient.

In addition, Mahler's study demonstrated that solutions in the realm of irreality ("magical thinking") have only a small substitute value in real-world task situations. This was also confirmed by the results of a study by Sarah Sliosberg (1934), which tested the substitute value of substitute objects. Playing and real situation are thus functionally clearly separated areas, which usually have no substitute value for each other. Another result of Sliosberg's study was that once a situation has fully developed, it is difficult to accept a substitute, and that it is easier to introduce a substitute as long as the person has not started to deal with the original object.

\subsection{Satiation}

Satiation is a state in which a person no longer wants to perform a certain activity. It was investigated by Anitra Karsten (1928/1976). Like the other experimenters, she gave the subjects various tasks. The instruction was to "work until you have enough." In some cases, she forced the subjects to keep working beyond this point. What did she find out?

Satiation does not increase continuously but shows an erratic course. Relative amenity changes with pronounced aversion. With increasing satiation, the subjects tend to introduce variations of the activity. If the subjects then continue a little further with their task, they experience a disintegration of Gestalt resp. a disintegration of the situation. 
Strong over-satiation leads to restless actions and emotional outbursts. Rejection and disgust of the activity then remain for a longer time and a co-satiation of neighboring psychic regions is likely.

Satiation is different from fatigue. One can, for example, be energetic again, if the previous activity is incorporated in something new. Activities that have a stronger positive or negative valence are satiated faster than more neutral ones.

For the time being, we can summarize: Whether something appears to be complete or unfinished is not an "objective" matter, but is determined by whether it is completed or not in the person's experience. For this, certain conditions can be stated to be relevant, which also means that you can do something specifically to foster a completion. Further, you can see the success of the effort by whether or not there occurs resumption after that. Life always creates situations in which an action cannot be completed in the original sense. In searching for appropriate substitute solutions, the investigations of Wera Mahler and her colleagues can be helpful. They emphasize the importance of the "degree of reality" and, most importantly, the significance of "social fact" for the effectiveness of a substitute solution.

The German saying "practice creates masters" is not entirely true. When a (quasi-) need is satisfied and the inner goal of the person is reached, the tension tends to decrease and the drive ceases. Uniform repetitions, which no longer allow the performer to experience further development, lead to over-satiation, thereby resulting in deterioration in performance and strongly negative emotional and motivational consequences. However, we can pay attention to the signs of satiation and provide for variations and variety early by embedding the activity in another or broader context.

\section{Structure of the Psyche, Tension, and Equilibrium}

So far, we have mainly dealt with the dynamics of a single tension system, with its emergence, its discharge, and satiation. However, the question remains as to how Lewin conceptualizes the functioning of the psyche as a whole and the cooperation required to be sustained among manifold needs and quasi-needs. We can hardly assume that such tension systems exist side by side in total isolation and that they only successively come into tension.

The single psychic tensions and energies, therefore, belong to systems, which in themselves represent dynamic units and show a higher or lesser degree of isolation. The quasi-needs in particular, which can be traced back to actions, do not represent isolated mental entities, but are mostly embedded in more comprehensive mental structures and are in communication with other quasi-needs and needs. 
According to Lewin, we can assume a tendency to equilibrium for the psychological field: Changes - from an idle state to an event or a change in a stationary equilibrium—are due to the fact that the equilibrium is disturbed, and processes are now starting to push in the direction of a new equilibrium. This equilibrium tendency only applies to the system as a whole; partial processes can run in the opposite direction. Equilibrium in Lewin's theory is therefore not a homeostatic state, but a flow equilibrium (steady state) in which conflicting forces at a certain level of pressure and counterpressure hold the balance.

In recent years, Norbert Andersch (2012) pointed out that Lewin's theory of tension systems was often misinterpreted as a relaxation theory. However, Lewin's main concern was to clarify where the energies for experience and action come from, how they are organized, and how they coordinate to guarantee people's complex life activity. In that sense, his interest in exploring the tension systems was not primarily about how to support their discharge; on the contrary, it was all about finding out what it takes to build up and hold sufficient tension to be able to pursue goals over longer periods of time and against adverse circumstances. Therefore, we can say that Lewin's concept of the psyche is about how manifold tension systems can be held in parallel (ibid., 31).

\section{Theory of Systems in Tension: Conclusions for Therapeutic Practice}

Gestalt theoretical psychotherapy relies mainly on Kurt Lewin's dynamic field theory of personality, in which the understanding of the dynamics of human experience and behavior is addressed. Since Lewin has excluded the question of the relationship of the life space to the non-psychological environment, which is highly relevant for psychotherapy and the question of how people can interact at all, his concept is "reinterpreted" by taking critical-realistic assumptions into account. This led to Stemberger's formulation of the multiple field approach in psychotherapy (2018).

Psychotherapy aims to help clients alleviate or overcome suffering. It is a collaborative, interactive endeavor of at least one therapist and one client, with the therapeutic relationship playing a central role. Client and therapist enter into a communication and relationship process that are intended to help the client to better understand herself/himself, to build up resources, and to find suitable solutions to her/his problems. The coordination between the interaction partners in the psychotherapeutic process can be understood as a field event ("psychotherapeutic field"). However, unlike, for example, psychoanalytic conceptions that took up Lewin's concept of field (Baranger \& Baranger, 2008; Ferro, 2003; Katz, 2017; cf. Stemberger, 2019), Gestalt theoretical psychotherapy emphasizes that we have to assume two psychotherapeutic fields: a psychotherapeutic field in the phenomenal world of the client and a psychotherapeutic field in the phenomenal 
world of the therapist. These can differ significantly from each other. What happens in the therapist's phenomenal world first has to become a fact in the client's phenomenal world in order to have any influence. ${ }^{6}$ This fact then can have a completely different function in the psychotherapeutic field of the client as compared to that in the psychotherapeutic field of the therapist (Stemberger, 2019, 64). With this in mind, the therapist has to constantly exchange interactions with the client to be able to do his/her job.

According to the field-theoretical approach, Gestalt-theoretical psychotherapy focuses on the psychological situation of the client and not on particular events, symptoms, or personality traits. The peculiarities of individual parts or characteristics are considered to be determined by the character of the psychological situation as a whole (Stemberger, 2018). Thus, the field-theoretical approach is not aimed at changing one single aspect, but at changing the overall situation, mainly by recentering or other forms of restructuring of the situation. Referring to the field-theoretical "principle of contemporaneity" (Lewin, 1936, 34) of the acting forces, we derive the understanding that the focus is on the here-and-now, including the psychological future and the psychological past as they are given therein.

Translated into praxeology, this requires, first, that the client achieves clarity about herself, her/his world, and her/his possibilities for action. The Gestalt theoretical therapist supports this by "practicing phenomenology" with the client (Stemberger, 2016). This means to help the client to explore her/his phenomenal world by seeing, hearing, feeling, sensing in an open, receptive attitude and taking the perceived, the felt, and the sensed seriously. The task of the therapist is to stimulate, support, and guide the client in this process. Because there is no direct access to the world of others, client and therapist are constantly reliant on exchange and dialog in this process.

If "practicing phenomenology" is about exploring "what is" and therefore addresses the phenomenal world of the client, the so called "force field analysis" addresses the forces acting on the life space. These forces cannot be perceived directly, but only through their effects. One could say that in this step, we are supporting the client to explore "what operates" in his world: What are the needs, goals, wishes, and intentions that underlie the forces? Do these needs, goals, and wishes have their origin in the client or are they induced from "others," who might be parents, partners, superiors, or society? What effects do they have on her/his experience and behavior, and how do they relate to the client's possibilities and situational requirements? The "field force analysis" in GTP is, of course, not a scientific but

\footnotetext{
6 More details on how the transmission of communication content between the phenomenal worlds of interacting people can be conceptualized in the critical-realistic model can be found in Bischof (1966) and Tholey (1986); refer also Sternek (2021).
} 
an experience-oriented analysis. Therefore, it is more an experimental than an intellectual undertaking. It takes advantage of the fact that with exploration and experimentation, the balance of forces in the field is already changing. This is one reason why in GTP we speak of the method of "change-activating" force-field analysis. The therapist develops his/her suggestions for experiments depending on the circumstances and requirements of the specific situation and thereby focuses on the relationships outside of therapy or the client-therapist relationship, as appropriate (cf. Böhm, 2021). However, the findings and results of the studies of the Lewin group can serve him/her as an orientation and idea generator.

Lewin's theory of tension systems sharpened our focus, especially on the positive, constructive side of tension in people's lives. Thus, they counterbalance the one-sided overemphasis of relaxation in many psychological approaches. Living systems need tension to be able to exist at all—without tension they do no longer live. In terms of psychotherapy, the task in many cases is not only to help bring about relaxation and the release of energy for something new through the completion of unfinished projects, but to do much more to support clients to build up and hold tensions, which they need to pursue important life tasks (Lindorfer $\&$ Stemberger, 2012). As we learned from the experimental work of the Lewin group, in this context, sufficient stability, a connection of goals with ego-near needs and the ability to engage in a cause are significant.

Finally, where unfinished businesses burden clients, the results of the experimental research give us clues as to how we can provide a conclusion: similarity to the inner goal, the greatest possible degree of reality (in the form of action or the creation of social facts), and an adequate degree of difficulty. The latter also refers to the case where someone sets his goals too high in relation to his inner and outer possibilities.

\section{Summary}

With regard to the dynamics of human experience and behavior, Gestalt theoretical psychotherapy (GTP) relies mainly on Kurt Lewin's dynamic field theory of personality. GTP is carried out by including a re-interpretation of Lewin's theory in some aspects of psychotherapeutic practice in relation to critical realism. Human experience and behavior are understood to be functions of the person and the environment (including the other individuals therein) in a psychic field (life space), which encompasses both of these mutually dependent factors. The anthropological model of this approach is, therefore, not mono-personal but, a priori, structural and relational in nature. It does not one-sidedly focus on the "inner components" of a person, but on the interrelation of the individual and a given environment, which affects experience and behavior. After a brief introduction of these basic concepts, this lecture will focus especially on Lewin's concept of tensionsystems, which may be considered as the Gestalt theoretical counterpart of Freud's drive theory. Further, we define the basic assumptions which underlie GTP and explain how the person moves through her/his life experience in terms of Gestalt psychology. 
Keywords: Gestalt theoretical psychotherapy, personality theory, field theory, life space, tension systems.

\section{Zusammenfassung}

In Hinblick auf die Dynamik menschlicher Erfahrung und menschlichen Verhaltens stützt sich die Gestalttheoretische Psychotherapie hauptsächlich auf Kurt Lewins dynamische Feldtheorie der Persönlichkeit. Dies geschieht einschließlich einer Neuinterpretation von Lewins Theorie in einigen Aspekten auf der Grundlage des kritischen Realismus. Menschliche Erfahrung und menschliches Verhalten werden als Funktionen der Person und der Umwelt (einschließlich der anderen Personen darin) in einem psychischen Feld (Lebensraum) verstanden, das diese beiden wechselseitig voneinander abhängigen Faktoren umfasst. Das anthropologische Modell dieses Ansatzes ist daher nicht monopersonal, sondern a priori struktureller und relationaler Natur. Es konzentriert sich nicht einseitig auf die "inneren Komponenten" einer Person, sondern auf die Wechselbeziehung des Individuums und einer bestimmten Umgebung, die sowohl die Erfahrung als auch das Verhalten beeinflusst. Nach einer kurzen Einführung in diese Grundkonzepte wird sich der Beitrag insbesondere auf Lewins Konzept der Spannungssysteme konzentrieren, das als gestalttheoretisches Gegenstück zu Freuds Triebtheorie angesehen werden kann. Innerhalb der Gestalttheoretischen Psychotherapie beschreibt es die Grundannahmen, wie sich die Person durch ihre Lebenserfahrung bewegt.

Schlüsselwörter: Gestalttheoretische Psychotherapie, Persönlichkeitstheorie, Feldtheorie, Lebensraum, Spannungsysteme.

\section{References}

Agazarian, Y. M. (1986). Application of Lewin's life space concept to the individual and group-as-a-whole systems in psychotherapy. In E. Stivers \& S. Wheelan (Eds.), The Lewin legacy: Field theory in current practice. New York: Springer-Verlag, pp. 101-112.

Agazarian, Y. M. (2004). System-Centered Therapy for Groups. New York, Routledge.

Andersch, N. (2012). Hans Carl Leuners Monographie: 'Die experimentelle Psychose' und sein Konzept einer 'konditional-genetischen Psychopathologie'. In B. Holdorff \& E. Kumbier (Ed.), Schriftenreihe der Deutschen Gesellschaft für Geschichte der Nervenheilkunde DGGN, Band 18, 197-212.

Baranger, M., \& Baranger, W. (2008/1961). The analytic situation as dynamic field. The International Journal of Psychoanalysis, 89, 795-826.

Beckmann, J. \& Heckhausen, H. (2018). Situational Determinants of Behavior. In Heckhausen, J. \& H. Heckhausen (Eds), Motivation and Action, 3rd edition, pp. 113-162.

Bischof, N. (1966). Erkenntnistheoretische Grundlagenprobleme der Wahrnehmungspsychologie. In W. Metzger \& H. Erke (Hrsg.), Handbuch der Psychologie in 12 Bdn. Bd. 1/I: Wahrnehmung und Bewusstsein (pp. S. 21-78). Göttingen, Germany: Verlag für Psychologie.

Böhm, A. (2021). Basic Principles for Therapeutic Relationship and Practice in Gestalttheoretical Psychotherapy. Gestalt Theory 43(1), pp.xx-xx.

Brown, J. F. (1929). The methods of Kurt Lewin in the psychology of action and affection. Psychological Review, 36, 200-221.

Corr, P. J., \& Matthews, G. (Ed.) (2009). The Cambridge handbook of personality psychology. Cambridge, UK: Cambridge University Press.

Ferro, A. (2003). Das bipersonale Feld. Konstruktivismus und Feldtheorie in der Kinderanalyyse. Gießen, Germany: Psychosozial Verlag.

Foschi, R., \& Lombardo, G. P. (2006). Lewinian contribution to the study of personality as the alternative to the mainstream of personality psychology in the 20th Century. In J. Trempata et al. (Eds.), Lewinian Psychology. Proceedings of the International Conference "Kurt Lewin: Contribution to Contemporary Psychology" Bydgoszcz, Poland: Kazimierz Wielky University Press. 86-98. 
Graefe, O. (1961). Über Notwendigkeit und Möglichkeit der psychologischen Wahrnehmungslehre. Psychologisehe Forschung, 26, 262-298.

Hall, C. S., \& Lindzey, G. (1978). Theories of personality (3rd ed.). Hoboken, NJ: John Wiley \& Sons.

Heckhausen, H. (1991). Motivation and Action. Berlin, Heidelberg, New York: Springer.

Karsten, A. (1928). Psychische Sättigung. Psychologische Forschung, 10, 142-154. [English translation: Karsten 1976]

Karsten, A. (1976). Mental satiation. in De Rivera (1976). Field theory as human science. Contributions of Lewin's Berlin Group. New York: Gardner Press, 151-207.

Katz, S.M. (2017). Contemporary psychoanalytic field theory: stories, dreams, and metaphor. New York: Routledge. Köhler, W. (1929). Ein altes Scheinproblem. Die Naturwissenschaften 17(22), pp. 395-401. Engl.: An Old Pseudoproblem. In Henle, M. (1971) (Ed.). The Selected Papers of Wolfgang Köhler. New York: Liveright, pp.125-141.

Köhler, W. (1968). Werte und Tatsachen. Berlin, Heidelberg, New York: Springer.

Leuner, H. C. (1997). Die experimentelle Psychose. Ihre Psychopharmakologie, Phänomenologie und Dynamik in Beziehung zur Person. Berlin, Germany: VWB.

Lewin, K. (1926a). Vorbemerkungen über die psychischen Kräfte und die Struktur der Seele. Psychologische Forschung, 7(4), 294-329.

Lewin, K. (1926b). Vorsatz, Wille und Bedürfnis. Psychologische Forschung, 7(4), 330-385.

Lewin, K. (1928). Die Entwicklung der experimentellen Willenspsychologie und die Psychotherapie. Archiv für Psychiatrie, 85, 515-537.

Lewin, K. (1935). A dynamic theory of personality. New York, London: McGraw-Hill.

Lewin, K. (1936). Principles of topological psychology. New York, London: Mc Graw-Hill.

Lewin, K. (1942). Time perspective and morale. In G. Watson (Ed.), Civilian morale. Boston, MA: Houghton Mifflin. 48-70.

Lewin, K. (1946 /1963). Behavior and development as a function of the total situation. In K. Lewin (1963), Feldtheorie in den Sozialwissenschaften, . Bern: Huber. 271-329.

Lindorfer, B. (2012a). Zeigarniks Pionierstudie zum Behalten erledigter und unerledigter Handlungen. Phänomenal - Zeitschrift für Gestalttheoretische Psychotherapie, 4(1-2), 71-73.

Lindorfer, B. (2012b). Ovsiankinas Pionierstudie zur Wiederaufnahme unterbrochener Handlungen. Phänomenal-Zeitschrift für Gestalttheoretische Psychotherapie, 4(1-2), 74-76.

Lindorfer, B. (2017). Spannungssystem. Lexikon zur Gestalttheoretischen Psychotherapie. Phänomenal Zeitschrift für gestalttheoretische Psychotherapie, 9(1). 55-57.

Lindorfer, B., \& Stemberger, G. (2012). Unfinished Business: Die Experimente der Lewin-Gruppe zu Struktur und Dynamik von Persönlichkeit und psychologischer Umwelt. Phänomenal - Zeitschrift für Gestalttheoretische Psychotherapie, 4(1-2), 63-70.

Lissner, K. (1933). Die Entspannung von Bedürfnissen durch Ersatzhandlungen. Psychologische Forschung, $18,218-250$.

Luchins, A. S., \& Luchins, E. H. (1999). Isomorphism in Gestalt theory: Comparison of Wertheimer's and Köhler's Concepts. Gestalt Theory, 21(3), 208-234.

Lück, H. (1996). Die Feldtheorie und Kurt Lewin. Weinheim, Germany: Beltz PVU

Mahler, W. (1933). Ersatzhandlungen verschiedenen Realitätsgrades. Psychologische Forschung, 18, $26-89$.

Marrow, A. J. (1969). Practical theorist - Life and work of Kurt Lewin. New York, NY: Basic Books.

Metzger, W. (1972). The phenomenal-perceptual field as a central steering mechanism. In J. R. Royce \& W. W. Rozeboom (Eds.), The psychology of knowing. New York/Paris/London: Gordon and Breach. 241-265.

Metzger, W. (1975/1986). Gestalttheorie und Gruppendynamik. In Metzger, W. (1986): Gestalt-Psychologie. Ausgewählte Werke aus den Jahren 1950 bis 1982 herausgegeben und eingeleitet von Michael Stadler und Heinrich Crabus. Frankfurt am Main, Germany: Verlag Waldemar Kramer.

Metzger, W. (1975/2001). Psychologie. Die Entwicklung ihrer Grundannahmen seit der Einführung des Experiments. 6. Auflage. Wien, Austria: Krammer.

Nuttin, J., \& Lens, W. (1985). Future time perspective and motivation: Theory and research method. Leuven, Belgium: Leuven University Press; Hillsdale, NJ: Erlbaum.

Ovsiankina, M. (1928). Die Wiederaufnahme unterbrochener Handlungen. Psychologische Forschung, 11, 302-379. [English translation: Rickers-Ovsiankina, 1976].

Rickers-Ovsiankina, M. (1976). The resumption of interrupted activities. In De Rivera, J. (1976). Field Theory as Human-Science. Contributions of Lewin's Berlin Group. New York: Gardner Press, 49-110.

Sliosberg, S. (1934). Zur Dynamik des Ersatzes in Spiel- und Ernstsituationen. Psychologische Forschung, 19, 122-181. 


\section{GESTALT THEORY, Vol. 43, No.1}

Soff, M. (2018). Gestalttheorie und Feldtheorie. In M. Hochgerner et al. (Hrsg.), Gestalttherapie. Zweite Auflage. Wien, Austria: Facultas. 13-43.

Spagnuolo-Lobb, M. (2010). The therapeutic relationship in Gestalt therapy.In Jacobs, L. \& Hycner, R. (eds., 2010). Relational Approaches in Gestalt Therapy. Santa Cruz, CA: Gestalt Press, 111-129.

Staemmler, F.-M. (2005). A babylonian confusion? On the uses and meanings of the term "field." British Gestalt Journal, 15(2), 64-83.

Stemberger, G. (2011). Grundzüge der Gestalttheoretischen Psychotherapie. Phänomenal - Zeitschrift für Gestalttheoretische Psychotherapie 3(2), pp. 12-18.

Stemberger, G. (2016). Phänomenologie treiben. Lexikon zur Gestalttheoretischen Psychotherapie. Phänomenal - Zeitschrift für Gestalttheoretische Psychotherapie, 8(1), 30-35.

Stemberger, G. (2017a). Machtfelder in der Psychotherapie, Teil 2. Phänomenal-Zeitschrift für Gestalttheoretische Psychotherapie, 8(1), 17-26.

Stemberger, G. (2017b). Arbeiten mit Machtfeldern. Phänomenal - Zeitschrift für Gestalttheoretische Psychotherapie, 9(1), 26-29.

Stemberger, G. (2018). Therapeutische Beziehung und therapeutische Praxis in der Gestalttheoretischen Psychotherapie (Teil 1). Phänomenal - Zeitschrift für Gestalttheoretische Psychotherapie, 10(2), 20-28.

Stemberger, G. (2019). Some remarks on the field concept in Gestalt psychology. Chapter in: Trombini, G., Corazza, A. \& G. Stemberger, G. (2019). Manifest Dream / Association Comparison: A Criterion to Monitor the Psychotherapeutic Field. Part 1. Gestalt Theory, 41(1), 61-78.

Sternek, K. (2021). Critical realism: The epistemic position of Gestalt theoretical psychotherapy. Gestalt Theory, 43(1).

Stolarski, M., Fieulaine, N., \& van Beek, W. (Eds.) (2015). Time perspective theory; Review, research and application. Essays in Honor of Philip G. Zimbardo. Cham Heidelberg New York Dordrecht London: Springer.

Tholey, P. (1980). Erkenntnistheoretische und systemtheoretische Grundlagen der Sensumotorik aus gestalttheoretischer Sicht. In Tholey, P. (2018). Gestalttheorie von Sport, Klartraum und Bewusstsein. Ausgewählte Arbeiten, herausgegeben und eingeleitet von Gerhard Stemberger. Wien: Krammer, 35-48.

Tholey, P. (1986). Deshalb Phänomenologie! Gestalt Theory 8(2), 144-163.

Tholey, P. (1996). Zur Einführung. In Walter H.-J. (1996). Angewandte Gestalttheorie in Psychotherapie und Psychohygiene. Opladen: Westdeutscher Verlag, 11-15.

Tholey, P. (1998). Feldtheorien in Biologie, Biophysik, Psychologie und Sozialwissenschaften. Ein bisher unveröffentlichter Kommentar (1995) aus dem Nachlass von Paul Tholey. ÖAGP-Informationen, 7(5), iii-ix.

Weiner, I. B., Millon, T., \& Lerner, M. J. (Ed.) (2003). Handbook of psychology, Vol. 5, personality and social psychology. Hoboden, NJ: John Wiley \& Sons.

Wicklund, R. A., \& Gollwitzer, P. M. (1981). Symbolic self-completion, attempted influence, and self-deprecation. Basic and Applied Social Psychology, 2(2), 89-114.

Wicklund, R. A., \& Gollwitzer, P. M. (1982). Symbolic self-completion. Hillsdale, N.J.: Lawrence Erlbaum.

Wollants, G. (2008). Gestalt therapy: Therapy of the situation. Turnhout, Belgium: Faculteit voor Mens en Samenleving. Reprint 2012 London: Sage Publications.

Zabransky, D., Wagner-Lukesch, E., Stemberger, G., \& Böhm, A. (2018). Grundlagen der Gestalttheoretischen Psychotherapie. In M. Hochgerner et al. (Hrsg.), Gestalttherapie. Zweite Auflage. Wien, Austria: Facultas. 132-169.

Zeigarnik, B. (1927). Über das Behalten von erledigten und unerledigten Handlungen. Psychologische Forscbung, 9, 1-85.

Zimbardo, P. G., \& Boyd, J. N. (1999). Putting time in perspective: A valid, reliable individual-differences metric. Journal of Personality and Social Psychology, 77(6), 1271-1288. Also in Stolarski et al. 2015, 17-56.

Bernadette Lindorfer, Clinical \& Health Psychologist, Psychotherapist and trainer for Gestalt Theoretical Psychotherapy in Vienna, Austria. Co-editor of Phänomenal-Zeitschrift für Gestalttheoretische Psychotherapie.

Address: Österreichische Arbeitsgemeinschaft für Gestalttheoretische Psychotherapie, Fünfhausgasse 5/20, 1150 Wien (Vienna), Austria

E-mail: bernadette.lindorfer@oeagp.at

ORCID: 0000-0002-4216-2564 